\title{
Isotherms for the adsorption of $\mathrm{Cu}$ (II) onto lignin - comparison of linear and non-linear methods
}

\author{
Mirjana M. Brdar, Aleksandar A. Takači, Marina B. Šćiban, Dušan Z. Rakić \\ University of Novi Sad, Faculty of Technology, Novi Sad, Serbia
}

\begin{abstract}
Equilibrium studies were carried out for the adsorption of $\mathrm{Cu}$ (II) onto Kraft lignin as an adsorbent. The experimental data were fitted to the Freundlich, Langmuir and Redlich-Peterson isotherms by linear and non-linear methods. Comparison of linear and non-linear regression methods was given in selecting the optimum isotherm for the experimental data. The coefficient of correlation $r^{2}$ and chi-square test $\chi^{2}$ were used to select the best linear theoretical isotherm. The best linear model is Redlich-Peterson isotherm model, where $r^{2}=0.985$ and $\chi^{2}=0.02$. In order to predict the error ERRSQ, HYBRD, MPSD, ARE and EABS were used. Moreover, by minimizing these error functions the optimal values of parameters and also the optimum isotherm was found. The Redlich-Peterson isotherm was found to be the best representative for adsorption of $\mathrm{Cu}(\mathrm{II})$ on the adsorbent in the cases when ERRSQ, HYBRD and MPSD functions were used. Their coefficients of determination were $0.986,0.985$ and 0.984 , respectively and chi-square was 0.02 in all cases. Freundlich isotherms obtained by minimization of the ERRSQ, HYBRD, MPSD, ARE and EABS function showed very good agreement with experimental data. In all cases the coefficients of determination were greater than 0.91 . Besides, it was observed that non-linear isotherm models were better for representation of equilibrium data than linearized models.
\end{abstract}

Keywords: adsorption isotherm, linear and non-linear methods, $\mathrm{Cu}(\mathrm{II})$, lignin.

SCIENTIFIC PAPER

UDC 66.081.3:546.56:665.947.4

Hem. Ind. 66 (4) 497-503 (2012)

doi: 10.2298/HEMIND111114003B

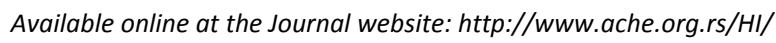

There is increasing interest in the development of economically viable new applications of lignin, which can be found as waste from cellulose and paper industry. This is evidenced by the existence of the International Lignin Institute, which promotes new technologies with lignin as the main component. Among others, the possibility of using lignin as an adsorbent for different pollutants from water has been considered [1]. Different functional groups of lignin provide binding of heavy metal ions. The lignin's capacity depends on its origin, type of metal ions and experimental conditions. In this work, the lignin is used as an adsorbent for copper ions. Copper has a number of important functions in the human body, but in large quantities, it also can cause different acute and chronic disorders. The World Health Organization's guideline for drinking water recommends the maximum permissible concentration for copper of $1 \mathrm{mg} / \mathrm{L}$ [2].

Equilibrium relationships between adsorbent and adsorbate are described by adsorption isotherms and characterized by certain constants, the values of which provide information on adsorbent capacity and affinity for some kind of adsorbate. In addition, the quality of the fit of experimental results indicates whether ad-

Correspondence: M. Brdar, Faculty of Technology, University of Novi Sad, Bulevar cara Lazara 1, 21000 Novi Sad, Serbia.

E-mail: mbrdar@tf.uns.ac.rs

Paper received: 14 November, 2011

Paper accepted: 30 December, 2011 sorption is monolayer or multilayer, on a homogeneous or heterogeneous surface. Isotherm equations do not consider which adsorption mechanisms, such as external mass transfer of solute, intraparticle diffusion or adsorption at sites, are decisive in the adsorption process, but can be used for design of batch adsorption systems. Some of the isotherm equations that can explain solid-liquid adsorption systems are: Langmuir, Freundlcih, Temkin, Sips, Toth, Redlich-Peterson isotherm equations [9].

Linear regression has been frequently used to determine the most fitted models and the method of least squares has been frequently used for finding the parameters of the models [3-6]. However, transformations of non-linear isotherm equations to linear forms implicitly alter their error structure and may also violate the error variance and normality assumptions of standard least squares. In recent years, several error analysis methods, such as the coefficient of determination, the sum of the errors squared, a hybrid error function, Marquardt's percent standard deviation, the average relative error and the sum of absolute errors, have been used to determine the best-fitting isotherm [7-10].

In this study, binding characteristics of $\mathrm{Cu}(\mathrm{II})$ on Kraft lignin were investigated and feasible application of different adsorption models for description of its adsorption on this low-cost and environment-friendly adsorbent was described. For that purpose, linear and non-linear equations of Freundlich, Langmuir and Red- 
lich-Peterson isotherm model (Table 1) were analyzed. The well-known least square method was used to predict the isotherm by linear regression method, i.e., the models were linearized and the parameters were found using the least square method. Generally, linearization leads to uncontrollable error margins, thus it is better to directly estimate the parameters of the model. For error estimation, ERRSQ, HYBRD, MPSD, ARE and EABS functions were used. Essentially, each of these functions is a distance function in the Cartesian plane. Since the optimal values of the parameters minimize the distances of experimental results from the model isotherm this means that the isotherm obtained by these methods is the best approximation of experimental results with respect to that distance function. The calculations were made using the Wolfram Research software Mathematica 6.

Namely, the purpose of this paper is that the experimental data obtained during the adsorption of copper ions on lignin serve as accurate representations of some commonly used models of adsorption isotherms, such as Freundlich, Langmuir and Redlich-Peterson. The aim is to highlight the role of the error function and the advantage of nonlinear methods in relation to linear ones.

\section{EXPERIMENTAL}

\section{Materials}

The $0.25 \mathrm{~mol} / \mathrm{L}$ stock solution of copper was prepared by dissolving the desired quantity of $\mathrm{CuSO}_{4} \cdot 5 \mathrm{H}_{2} \mathrm{O}$ in one liter of distilled water. Prior to the adsorption experiments, water solutions of different copper concentrations were prepared by dilution of stock solutions by distilled water and $\mathrm{pH}$ adjusment was made using $\mathrm{HCl}$ solution. All chemicals used were of analytical reagent grade.
Kraft lignin was obtained from the sulphate pulping process of poplar and beech wood (70:30) conducted in a pulp mill. Lignin was precipitated from black liquor with sulphuric acid and washed by distilled water. After filtering and drying at room temperature, the obtained lignin was in the form of fine black-brown powder (particle size $<0.25 \mathrm{~mm}$ ). The BET surface area of Kraft lignin was measured and it was found to be $0.77 \mathrm{~m}^{2} / \mathrm{g}$ (Micrometrics, ASAP 2000, USA), which classifies it into adsorbents with a small surface area.

\section{Batch adsorption studies}

Batch adsorption experiments were carried out by shaking $5 \mathrm{~g}$ of Kraft lignin in $1 \mathrm{~L}$ of aqueous copper solution with different concentration ( 5 to $200 \mathrm{mg} / \mathrm{L}$ ), at $\mathrm{pH}$ 4. The adsorption experiments were done at this $\mathrm{pH}$ value in accordance with results of previous investigations $[11,12]$. That $\mathrm{pH}$ value is below the onset of metal hydroxid precipitation and then the copper is mostly in the form of $\mathrm{Cu}^{2+}$. The suspensions were shaken for $3 \mathrm{~h}$ at an agitation speed of $110 \mathrm{rpm}$. This contact time was sufficient to reach equilibrium [12]. After reaction time, the suspensions were filtered through a Gooch G4 funnel. The concentrations of copper ions in the aqueous solutions before $\left(c_{0}\right)$ and after adsorption $(c)$ were determined using a Pye-Unicam SP 191 atomic absorption spectrophotometer (Cambridge, UK). Experiments were performed in duplicate and the results were averaged.

The amount of copper ions adsorbed per specified amount of adsorbent, $q$, was calculated as follows:

$$
q=\frac{c_{0}-c}{m}
$$

where $m$ is mass of adsorbent per liter of solution.

\section{Adsorption isotherms}

All isotherm equations and their linearized forms are presented in Table 1.

Table 1. Models of isotherm equation

\begin{tabular}{lcc}
\hline Ishoterm & Non-linear equation & Linear equation \\
\hline Freundlich & $q=K_{\mathrm{F}} c^{1 / n}$ & $\log q=\frac{1}{n} \log c+\log K_{\mathrm{F}}$ \\
Langmuir-1 & $q=\frac{q_{\mathrm{m}} K_{\mathrm{L}}}{1+K_{\mathrm{L}} c}$ & $\frac{c}{q}=\frac{1}{q_{\mathrm{m}}} c+\frac{1}{K_{\mathrm{L}} q_{\mathrm{m}}}$ \\
Langmuir-2 & & $\frac{1}{q}=\frac{1}{K_{\mathrm{L}} q_{\mathrm{m}}} \frac{1}{c}+\frac{1}{q_{\mathrm{m}}}$ \\
Langmuir-3 & $q=-\frac{1}{K_{\mathrm{L}}} \frac{q}{c}+q_{\mathrm{m}}$ \\
Langmuir-4 & $\frac{q}{c}=-K_{\mathrm{L}} q+K_{\mathrm{L}} q_{\mathrm{m}}$ \\
Redlich-Peterson & $\frac{A c}{1+B c^{g}}$ & $\ln \left(\frac{A}{q}-1\right)=g \ln c+\ln B$ \\
\hline
\end{tabular}


The Freundlich equation is an empirical model that considers heterogeneous adsorptive energies on the adsorbent surface [13]. The parameters of this isotherm can be obtained from the slope and intercept of plot $\log q$ versus $\log c$.

The magnitude of the Freundlich adsorption capacity $n$ gives an indication of the favorability of adsorption. The values of $n$ in the range from 2-10 indicate good adsorption capacity, 1-2 moderate adsorption capacity and less than 1 indicate poor adsorption capacity.

The Langmuir isotherm equation is derived from simple mass kinetics, assuming chemisorption [14]. This model is based on two assumptions: the forces of interaction between adsorbed molecules are negligible and once a molecule occupies a site no further adsorption takes place. In this paper the Langmuir isotherms were linearized to four different types. The Langmuir-1 isotherm was the most commonly used linear expression to study the relation between the concentration of solute in liquid phase and in the solid phase at equilibrium conditions. The Langmuir-2 isotherm was also used to explain the equilibrium phenomena of dye adsorption processes. The values of Langmuir constants $q_{\mathrm{m}}$ and $K_{\mathrm{L}}$ can be calculated from the plots: $c / q=f(c)$, $1 / q=f(1 / c), q=f(q / c)$ and $q / c=f(q)$ for Langmuir-1, $-2,-3$ and -4 isotherms, respectively.

The Redlich-Peterson isotherm [15], contains three parameters, $A, B$ and $g$ and the form of the equation includes features of the Langmuir and Freundlich isotherms. The exponent, $g$, lies between 0 and 1 . Thus, when $g=1$, the Redlich-Peterson equation becomes the Langmuir equation, and, when $g=0$, equation presents the Henry's law. This equation can be converted into a linear form but, the isotherm constants are not possible to obtain because of the three unknowns. The constant $A$ was obtained by maximizing the value of coefficient of determination using software package Mathematica 6.

\section{RESULTS AND DISCUSSIONS}

As a suitable measure for determination of the relationship between independent and dependent variables, the coefficient of determination was used:

$$
r^{2}=\frac{\sum_{i=1}^{p}\left(q_{\text {meas }}-\bar{q}_{\text {calc }}\right)^{2}}{\sum_{i=1}^{p}\left(q_{\text {meas }}-\bar{q}_{\text {calc }}\right)^{2}+\sum_{i=1}^{p}\left(q_{\text {meas }}-q_{\text {calc }}\right)^{2}}
$$

and chi-square test:

$\chi^{2}=\sum_{i=1}^{p} \frac{\left(q_{\text {meas }}-q_{\text {calc }}\right)^{2}}{q_{\text {meas }}}$

where $p$ denotes the number of experimental data, $q_{\text {calc }}$ is calculated equilibrium solid phase concentration, $q_{\text {meas }}$ is measured equilibrium solid phase concentration and $\bar{q}_{\text {calc }}$ is the average of $q_{\text {calc }}$. The advantage of using the chi-square test was the comparison of all isotherms on the same abscissa and ordinate. If data from the model were similar to the experimental data, $\chi^{2}$ would be a small number or vice versa.

\section{Linear method}

The simplest method for determination of the isotherm constants for two parameter isotherms is to linearize the model equation and then apply linear regression.

From Table 2, it was observed that the Langmuir constants varied for different forms of linear Langmuir equations. This is because depending on the way isotherm is linearized, the error distribution changes either the worse or the better. All types of linearized Langmuir equation give a lower coefficient of determination and higher values of the chi-squared test compared to Freundlich and Redlich-Peterson isotherms and that suggests that the Langmuir equation is not appropriate to use. From Table 2 it can be seen that the Freundlich constant related to the adsorption intensity $(n)$ is between 6 and 7, which indicated that lignin has high affinity for copper removal. Also, high value of $r^{2}$ and the very small values of $\chi^{2}$ for both Freundlich and Redlich-Peterson isotherms suggest that both models can be used to explain copper adsorption behavior. Based on these results it can be concluded that the surface area of Kraft lignin is heterogenous with different adsorption sites. The capacity of lignin for copper ions is simmilar to other lignocellulosic adsorbents $[1,16]$.

Table 2. Isotherm parameters obtained by linear regression method

\begin{tabular}{|c|c|c|c|c|c|c|c|c|c|}
\hline Ishoterm & $K_{\mathrm{F}} / \mathrm{mg} \mathrm{g}^{-1}\left(\mathrm{~L} \mathrm{mg}^{-1}\right)^{n}$ & $q_{\mathrm{m}} / \mathrm{mg} \mathrm{g}^{-1}$ & $A / \mathrm{Lg}^{-1}$ & $B / \mathrm{L} \mathrm{mg}^{1-1 / A}$ & $K_{\mathrm{L}} / \mathrm{L} \mathrm{mg}^{-1}$ & $1 / n$ & $g$ & $r^{2}$ & $\chi^{2}$ \\
\hline Freundlich & 1.628130 & - & - & - & - & 0.148632 & - & 0.943476 & 0.13957 \\
\hline Langmuir-1 & - & 3.37995 & - & - & 0.246773 & - & - & 0.788194 & 1.89191 \\
\hline Langmuir-2 & - & 2.64700 & - & - & 11.54270 & - & - & 0.734178 & 0.32631 \\
\hline Langmuir-3 & - & 2.73844 & - & - & 10.65550 & - & - & 0.767616 & 0.32502 \\
\hline Langmuir-4 & - & 2.85213 & - & - & 8.139280 & - & - & 0.811769 & 0.34907 \\
\hline Redlich-Peterson & - & - & 50.321 & 25.101 & - & - & 0.90732 & 0.985890 & 0.02057 \\
\hline
\end{tabular}


Therefore, from Figure 1 it can be seen that the Redlich-Peterson linearized isotherm model gave the best fit of the experimental data and explained the adsorption isotherm of copper onto lignin. Points on the graphs represent the experimental data.

\section{Non-linear methods}

Due to the inherent bias from linearization, alternative isotherm parameter sets were determined by non-linear regression. This provides a mathematically rigorous method for determining the isotherm parameters by using the original form of the isotherm equation. The optimization procedure requires the selection of an error function in order to evaluate the fit of the isotherm to the experimental data. The choice of error function can affect the parameters derived-error functions based primarily on absolute deviation bias the fit towards high concentration data and this weighting increases when the square of the deviation is used to penalize extreme errors.

ERRSQ - the sum of the squares of the errors:

$$
\sum_{i=1}^{p}\left(q_{\text {meas }}-q_{\text {calc }}\right)_{i}^{2}
$$

HYBRD - a composite fractional error function:

$\sum_{i=1}^{p}\left[\frac{\left(q_{\text {meas }}-q_{\text {calc }}\right)^{2}}{q_{\text {meas }}}\right]_{i}$

MPSD - a derivative of Marquardt's percent standard deviation:

$$
\sum_{i=1}^{p}\left(\frac{q_{\text {meas }}-q_{\text {calc }}}{q_{\text {meas }}}\right)_{i}^{2}
$$

ARE - the average relative error:

$\sum_{i=1}^{p}\left|\frac{q_{\text {meas }}-q_{\text {calc }}}{q_{\text {meas }}}\right|_{i}$

EABS - the sum of the absolute errors:

$\sum_{i=1}^{p}\left|q_{\text {meas }}-q_{\text {calc }}\right|_{i}$

where $p$ denotes the number of experimental data.

The explanations of various error functions used in the present study are given in Table 3 for Freundlich Equation, in Table 4 for Langmuir Equation and in Table 5 for Redlich-Peterson Equation. The Freundlich Equation showed a very good agreement with our experimental data (Figure 2). It had a high value of $r^{2}$ and low value of $\chi^{2}$ for all error function. The constant related to adsorption capacity was about 7 , which shows that copper has very good adsorption characteristics.

Table 3. Freundlich isotherm parameters obtained by minimizing the error distribution using different error functions

\begin{tabular}{lcccc}
\hline $\begin{array}{l}\text { Error } \\
\text { function }\end{array}$ & $\begin{array}{c}K_{\mathrm{F}} \\
\mathrm{mg} \mathrm{g}^{-1}\left(\mathrm{~L} \mathrm{mg}^{-1}\right)^{n}\end{array}$ & $1 / n$ & $r^{2}$ & $\chi^{2}$ \\
\hline ERRSQ & 1.73963 & 0.126931 & 0.946787 & 0.152916 \\
HYBRD & 1.65148 & 0.140541 & 0.947579 & 0.170677 \\
MPSD & 1.58033 & 0.153541 & 0.939755 & 0.147579 \\
ARE & 1.45579 & 0.163123 & 0.915080 & 0.216095 \\
EABS & 1.62633 & 0.139970 & 0.943019 & 0.135953 \\
\hline
\end{tabular}

As it can be seen from the Table 4, the Langmuir isotherm does not represent the equilibrium equation well, but all error functions give the approximately the same value for $q_{m}$ (Figure 3).

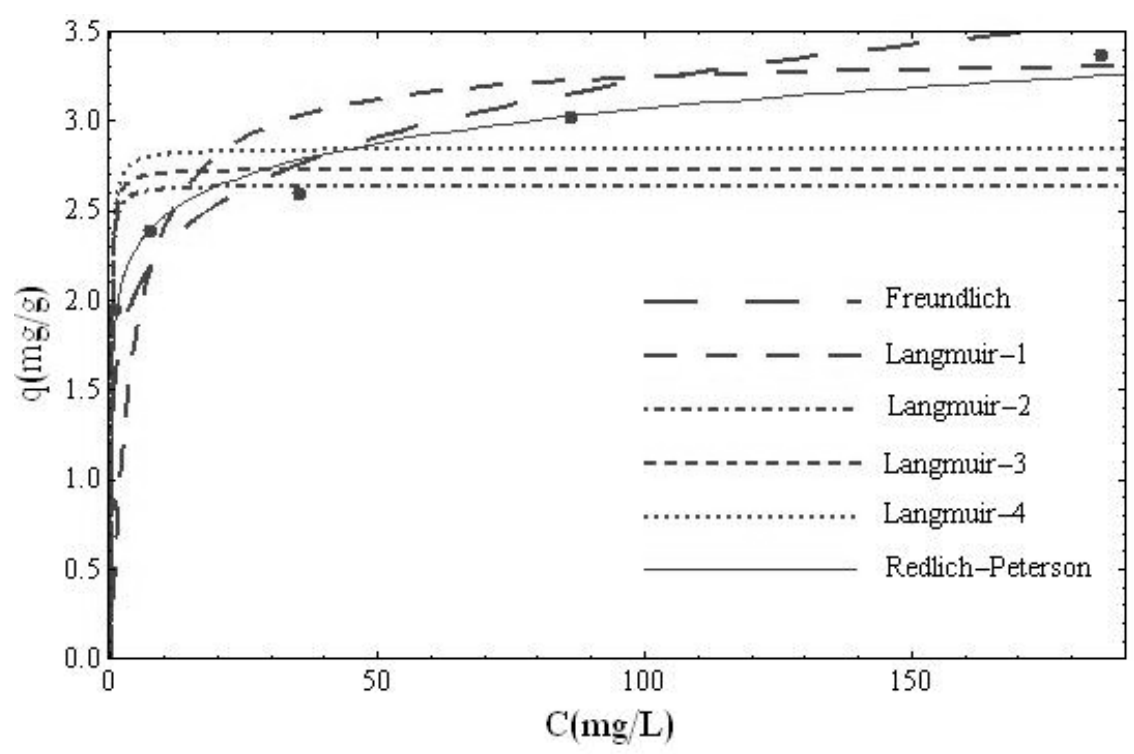

Figure 1. Isotherms obtained using the linear method for the adsorption of copper ions onto lignin. 
Table 4. Langmuir isotherm parameters obtained by minimizing the error distribution using different error functions

\begin{tabular}{lcccc}
\hline Error function & $q_{\mathrm{m}} / \mathrm{mg} \mathrm{g}^{-1}$ & $K_{\mathrm{L}} / \mathrm{L} \mathrm{mg}^{-1}$ & $r^{2}$ & $\chi^{2}$ \\
\hline ERRSQ & 2.8514 & 4.19223 & 0.858974 & 0.426817 \\
HYBRD & 2.70171 & 9.39488 & 0.778946 & 0.314164 \\
MPSD & 2.61213 & 11.1800 & 0.728865 & 0.329032 \\
ARE & 2.60625 & 11.8894 & 0.716251 & 0.334938 \\
EABS & 3.04206 & 2.19007 & 0.876446 & 0.617294 \\
\hline
\end{tabular}

Table 5 shows that the error functions ARE and EABS have low $r^{2}$ and higher values of $\chi^{2}$ than other error functions. This indicates that the ARE and EABS error functions are not good approximations of experimental data with the model isotherm. The cause lies in the definition of these errors. But, the ERRSQ, HYBRD and MPSD give excellent results of isotherm parameters. If we consider only the first five error functions (ERRSQ, HYBRD and MPSD), it can be concluded that Redlich-Peterson provides better agreement than the Freundlich isotherm model.

Table 5. Redlich-Peterson isotherm parameters obtained by minimizing the error distribution using different error functions

\begin{tabular}{lccccc}
\hline $\begin{array}{l}\text { Error } \\
\text { function }\end{array}$ & $\begin{array}{c}A \\
\mathrm{Lg}^{-1}\end{array}$ & $\begin{array}{c}B \\
\mathrm{~L} \mathrm{mg}^{1-1 / A}\end{array}$ & $g$ & $r^{2}$ & $\chi^{2}$ \\
\hline ERRSQ & 53.1769 & 26.7504 & 0.904783 & 0.986118 & 0.021119 \\
HYBRD & 49.6404 & 24.6554 & 0.908584 & 0.985636 & 0.020521 \\
MPSD & 47.6677 & 23.4299 & 0.912062 & 0.984437 & 0.020971 \\
ARE & 0.91548 & 0.29720 & 0.995192 & 0.782122 & 1.809790 \\
EABS & 2.57947 & 1.18709 & 0.922565 & 0.849041 & 1.112110 \\
\hline
\end{tabular}

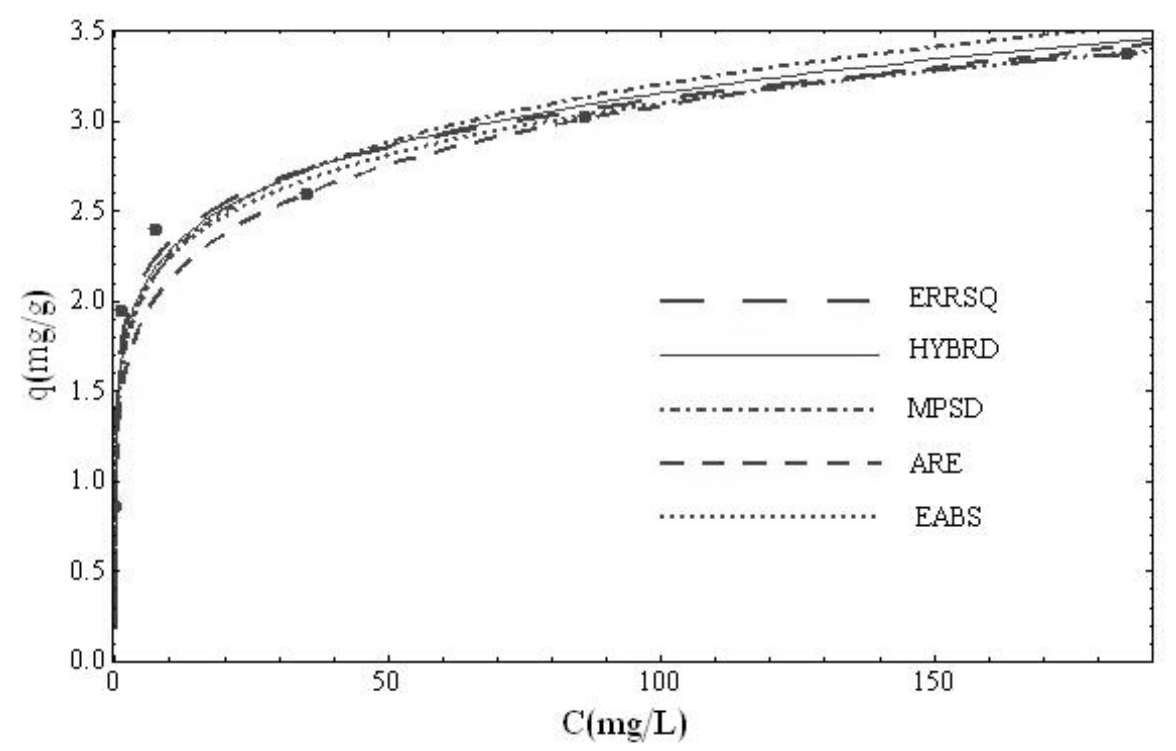

Figure 2. Freundlich isotherms obtained using the non-linear method for the adsorption of copper ions onto lignin.

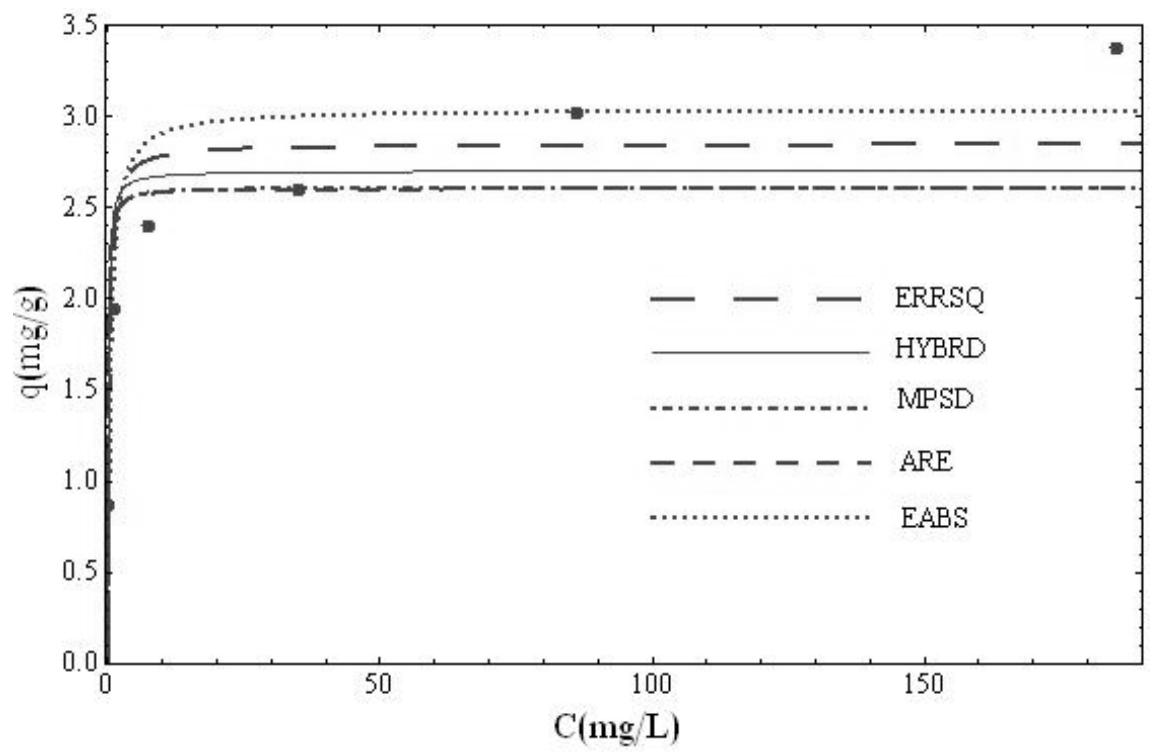

Figure 3. Langmuir isotherms obtained using the non-linear method for the adsorption of copper ions onto lignin. 


\section{CONCLUSION}

The equilibrium adsorption of copper ions onto Kraft lignin was explained using the Freundlich, Langmuir and Radlich-Peterson isotherms. Often, linearization is used for estimating the adsorption characteristics of certain adsorption systems, due to the simplicity in estimation. The Redlich-Peterson isotherm was found to be the best model, with $r^{2}=0.985$ and $\chi^{2}=$ $=0.02$. The present investigations showed that the nonlinear method is a better way to obtain the isotherm parameters. Freundlich isotherms obtained by minimization of the ERRSQ, HYBRD, MPSD, ARE and EABS functions show very good agreement with experimental data. In all cases the coefficients of determination were greater than 0.91. For the three-parameter isotherm (Redlich-Peterson isotherm), ERRSQ, HYBRD and MPSD functions were found to be an equally good option to minimize the error. Error functions ARE and EABS are not the best choice for determining isotherms. In linear and non-linear methods, where we used ERRSQ, HYBRD and MPSD function, the experimental equilibrium data of copper ions onto lignin showed the best results represented by the Redlich-Peterson isotherm equation. Their coefficients of determination were $0.986,0.985$ and 0.984 , respectively, and chi-square was 0.02 in all cases.

\section{Nomenclature}

\begin{tabular}{|c|c|}
\hline$K_{\mathrm{F}}(\mathrm{mg} / \mathrm{g})(\mathrm{L} / \mathrm{mg})^{n}$ & Constant for Freundlich equation \\
\hline$n$ & Constant for Freundlich equation \\
\hline$K_{\mathrm{L}}(\mathrm{L} / \mathrm{mg})$ & Constant for Langmuir equation \\
\hline$q_{\mathrm{m}}(\mathrm{mg} / \mathrm{g})$ & $\begin{array}{l}\text { Saturation capacity-constant for } \\
\text { Langmuir }\end{array}$ \\
\hline$C(\mathrm{mg} / \mathrm{L})$ & Fluid adsorbate concentration \\
\hline$q(\mathrm{mg} / \mathrm{g})$ & Solid adsorbate concentration \\
\hline$A(\mathrm{~L} / \mathrm{g})$ & $\begin{array}{l}\text { Constant for Redlich-Peterson equa- } \\
\text { tion }\end{array}$ \\
\hline$B\left(\mathrm{~L} / \mathrm{mg}^{1-1 / A}\right)$ & $\begin{array}{l}\text { Constant for Redlich-Peterson equa- } \\
\text { tion }\end{array}$ \\
\hline$g$ & $\begin{array}{l}\text { Exponent in Redlich-Peterson iso- } \\
\text { therm }\end{array}$ \\
\hline
\end{tabular}

\section{Acknowledgement}

The work presented here was supported by the Ministry of Education, Science and Technological Development of the Republic of Serbia (Project III44006 and Project III43005).

\section{REFERENCES}

[1] P. J. M. Carrott, M. M. L. R. Carrott, Lignin - from natural adsorbent to activated carbon: A review. Biores. Technol. 98 (2006) 2301-2312.

[2] WHO, Guidelines for Drinking Water Quality, Recommendations, vol. I, WHO, Geneva, 1984.

[3] Y.S. Ho, Isotherms for the sorption of lead onto peat: Comparison of linear and non-linear methods, Pol. J. Environ. Stud. 15 (2006) 81-86.

[4] K.V. Kumar, K. Porkodi, Batch adsorber design for different solution volume/adsorbent mass ratios using the experimental equilibrium data with fixed solution volume/adsorbent mass ratio of malachite green onto orange peel, Dyes Pigments 74 (2007) 590-594.

[5] K.V. Kumar, S. Sivanesan, Isotherm parameters for basic dyes onto activated carbon: Comparison of linear and non-linear method, J. Hazard. Mater. B129 (2006) 147-150 .

[6] B. Subramanyam, A. Das, Linearized and non-linearized isotherm models comparative study on adsorption of aqueous phenol solution in soil, Int. J. Environ. Sci. Tech. 6 (2009) 633-640.

[7] A. Alihosseini, V. Taghikhani, A.A. Safekordi, D. Bastani, Equilibrium sorption of crude oil by expanded perlite using different adsorption isotherms at $298.15 \mathrm{~K}$, Int. J. Environ. Sci. Tech. 7 (2010) 591-598.

[8] L.R. Chevalier, Use of optimization to develop a correlation model for predicting residual NAPL Saturation, Civ. Eng. Environ. Syst. 23 (2006) 65-72.

[9] Y.S. Ho, J.F. Porter, G. McKay, Equilibrium isotherm studies for the sorption of divalent metal ions onto peat: Copper, nickel and lead single component systems, Water Air Soil Poll. 141 (2002) 1-33.

[10] K.V. Kumar, K. Porkodi, F. Rocha, Isotherms and thermodynamics by linear and non-linear regression analysis for the sorption of methylene blue onto activated carbon: Comparison of various error functions, J. Hazard. Mater. 151 (2008) 794-804.

[11] M. Ajmal, A.H. Khan, S. Ahmad, A. Ahmad, Role of sawdust in the removal of copper(II) from industrial wastes, Water Res. 22 (1998) 3085-3091.

[12] M. Šćiban, M. Klašnja, Study of the adsorption of copper(II) ions from water onto wood sawdust, pulp and lignin, Adsorp. Sci. Technol. 22 (2004) 195-206.

[13] H.M.F. Freundlich, Over the adsorption in solution, Z. Phys. Chem. 57A (1906) 385-470.

[14] I. Langmuir, The constitution and fundamental properties of solids and liquids, J. Am. Chem. Soc. 38 (1916) 2221-2295.

[15] O. Redlich, D. L. Peterson, A useful adsorption isotherm, J. Phys. Chem. 63 (1959) 1024.

[16] A. Demirbas, Heavy metal adsorption onto agro-based waste materials: A review, J. Hazard. Mater. 157 (2008) 220-229. 


\section{IZVOD}

\section{IZOTERME ZA ADSORPCIJU CU(II) NA LIGNINU - POREĐENJE LINEARNIH I NELINEARNIH METODA}

Mirjana M. Brdar, Aleksandar A. Takači, Marina B. Šćiban, Dušan Z. Rakić

Univerzitet u Novom Sadu, Tehnološki fakultet, Novi Sad, Srbija

(Naučni rad)

U ovom radu izvršena su ispitivanja adsorpcije Cu(II) na Kraft ligninu kao adsorbentu. Eksperimentalni podaci su fitovani Freundlichovom, Langmuirovom i Redlich-Petersonovom izotermom linearnim i nelinearnim metodama. Dato je poređenje linearnog i nelinearnog metoda regresije u određivanju optimalne izoterme za date eksperimentalne podatke. Koeficijent korelacije $r^{2}$ i hi-kvadrat test, $\chi^{2}$, korišćeni su za određivanje najbolje linearne, teorijske izoterme. Najbolji linearni model je Redlich-Petersonov model, gde je $r^{2}=0,985$ i $\chi^{2}=0,02$. U slučaju nelinearnog regresionog metoda korišćeno je pet funkcija greške: ERRSQ, HYBRD, MPSD, ARE i EABS. Rezultati pokazuju da Redlich-Petersonova izoterma najbolje predstavlja sorpciju $\mathrm{Cu}(\mathrm{II})$ na Kraft lignin prilikom korišćenja ERRSQ, HYBRD i MPSD funkcija. Koeficijenti determinacije su 0,986, 0,985 i 0,984, redom, a hi-kvadrat je 0,02 u ovim slučajevima. Freundlichova izoterma dobijena minimizacijom ERRSQ, HYBRD, MPSD, ARE i EABS pokazuje veoma dobra slaganja sa eksperimentalnim podacima. U svim slučajevima koeficijenti determinacije su veći od 0,91 . Osim toga, primećeno je da parametri izotermi dobijeni nelinearnim metodama bolje opisuju adsorpciju jona bakra na ligninu od onih koji su dobijeni linearnim metodama.

Ključne reči: Adsorpciona izoterma $\bullet$ Linearne i nelinearne metode $\bullet \mathrm{Cu}(\mathrm{II}) \bullet \mathrm{Li}$ gnin 